\title{
BIBLIOBUSNA SLUŽBA U PROMICANJU AGENDE UN-A ZA ODRŽIVI RAZVOJ - PRIMJERI DOBRE PRAKSE
}

\author{
MOBILE LIBRARY SERVICE IN PROMOTING \\ THE GOALS OF THE UN AGENDA FOR SUSTAINABLE \\ DEVELOPMENT - EXAMPLES OF GOOD PRACTICE
}

Nika Čabrić
Knjižnice grada Zagreba
nika.cabric@kgz.h
Tamara Kolić
Knjižnice grada Zagreba
tamara.kolic@kgz.hr
Davorka Semenić Premec
Knjižnice grada Zagreba
davorka.semenic.premec@kgz.hr

UDK / UDC 021.65: [061.1UN: 332.146.2]

Stručni rad / Professional paper

Primljeno / Received: 15. 9. 2019.

Prihvaćeno / Accepted: 11. 11. 2019.

\section{Sažetak}

Cilj. Cilj je rada prikazati mogućnosti, dosege i dobru praksu rada Bibliobusne službe Knjižnica grada Zagreba u promicanju UN-ove Agende za održivi razvoj 2030. Svojim radom trenutno nastoji doprinijeti sljedećim ciljevima: Cilju 4. - Kvalitetno obrazovanje, Cilju 10. - Smanjenje nejednakosti, Cilju 11. - Održivi gradovi i lokalne zajednice, Cilju 16. - Mir i pravednost, Cilju 17. - Partnerstvo za ciljeve.

Pristup/metodologija/dizajn. Rad je nastao na temelju kronološkog praćenja primjera dobre prakse nastalih u radu Bibliobusne službe Knjižnica grada Zagreba, a koji doprinose ostvarenju zadanih ciljeve Agende Ujedinjenih naroda za održivi razvoj 2030 .

Vjesnik bibliotekara Hrvatske 62, 2(2019), 213-226

ISSN 0507-1925 
Rezultati. Sukladno evaluaciji bibliobusnih stajališta u lipnju, početkom sljedeće školske godine otvaraju se nova te zatvara dio postojećih stajališta za koja je utvrđeno da više nisu potrebna u Gradu Zagrebu i Zagrebačkoj županiji. Reorganizacija se radi s ciljem promicanja jednakopravnosti u pružanju knjižničnih usluga i povećavanja mogućnosti pristupa istima. Misija je omogućiti svima jednak pristup knjižničnoj građi, informacijama i znanju. U 2018. godini Bibliobusna služba obilazi 77 stajališta, od kojih je 55 u Gradu Zagrebu, a 22 u Zagrebačkoj županiji. Ukupan broj članova je 4505, od kojih su 2870 djeca, a 1635 odrasli. Unutar Projekta 65 Plus, programom Knjigom do vrata surađuje se s domovima za starije i nemoćne osobe i individualno posjećuje korisnike. Intenzivirana je i nabava audiovizualne i elektroničke građe koja obuhvaća i prilagođenu građu u DAISY-book-formatu, namijenjenu slijepim i slabovidnim osobama.

Društveni značaj. Promicanje jednakopravnosti u pružanju najprilagodljivije knjižnične usluge povećavanjem mogućnosti pristupa istima prema potrebama promjenjivog stanovništva bez obzira na mjesto stanovanja.

Originalnost/vrijednost. Rad je prikaz primjera dobre prakse i poslovanja Bibliobusne službe od 2017., kada se organizacijom i realizacijom vlasitith programa aktivno uključila u promicanje projekata, aktivnosti i manifestacija kao što su Mjesec hrvatske knjige, Projekt 65 plus, Kampanja Čitaj mi!, Noć muzeja, Noć knjige, Dani medijske pismenosti.

Ključne riječi: Agenda UN-a, bibliobus, Bibliobusna služba, Knjižnice grada Zagreba, pokretna knjižnica

\begin{abstract}
Purpose. The aim of the paper is to present the possibilities, achievements and good practices of the Mobile Library Service of the Zagreb City Libraries that aim to achieve the goals of the UN Agenda for Sustainable Development 2030. The Mobile Library Service is included in many activities of the Zagreb City Libraries. Currently, the Mobile Library Service is contributing to the following Agenda objectives: Objective 4 Quality education, Objective 10 - Reducing inequality, Objective 11 - Sustainable cities and local communities, Objective 16 - Peace and equality, Objective 17 - Partnership for goals.
\end{abstract}

Approach/methodology/design. The paper is based on a chronological follow-up of good practice examples of the Mobile Library Service of the Zagreb City Libraries which contribute to achieving the stated goals of the United Nations 2030 Agenda for Sustainable Development.

Findings. In accordance with the evaluation of the regularly scheduled stops of the Bookmobile Service in June, a number of new stops will be opened at the beginning of the next school year, and some of the existing ones will be closed because the evaluation has shown that they are no longer needed in the City of Zagreb and the Zagreb County. 
The reorganization is aimed at promoting equality in the provision of library services and enhancing access to them. The mission is to provide everyone with equal access to library materials, information and knowledge. In 2018, the Mobile Library Service visited 77 stops, out of which 55 are in the City of Zagreb and 22 in the Zagreb County. The total number of mobile library members was 4,505 , out of which 2,870 were children and 1,635 were adults. Within the Project 65 Plus, in the Book-to-Door program, the library collaborates with the nursing homes and visits the users individually. The acquisition of audiovisual and electronic material has also been intensified, including tailored material in the DAISY book format, intended for the blind and partially sighted persons.

Social implications. The Mobile Library Service promotes equal opportunities providing the most customizable library service by increasing access and thus meeting the needs of the changing population regardless of the place of residence.

Originality/value. The paper is an example of good practice and activities of the Mobile Library Service since 2017, when it started to actively organize and implement its own programs to promote projects, activities, and events such as the Croatian Book Month, the 65 Plus Project, Read to Me!, the Night of the Museums, the Book Night, the Days of Media Literacy campaign.

Keywords: Bookmobile, Mobile Library Service, UN Agenda, Zagreb City Libraries

\section{Uvod}

Središnja tema 43. Skupštine Hrvatskog knjižničarskog društva koja se održala u listopadu 2018. godine u Opatiji bila je Uloga i mogućnosti knjižnica u ostvarivanju globalnih ciljeva održivog razvoja UN Agende 2030. ${ }^{1}$ Ta tema usko je povezana sa strateškim dokumentom Agende Ujedinjenih naroda za održivi razvoj 2030. koju su u rujnu 2015. godine, pod nazivom Promijeniti svijet: program Ujedinjenih naroda za održivi razvoj 2030., usvojile sve zemlje članice Ujedinjenih naroda.

U kontekstu Agende za održivi razvoj 2030., IFLA vjeruje da omogućavanje pristupa informacijama i znanju svima, uz pomoć informacijske i komunikacijske tehnologije, doprinosi održivom razvoju i kvaliteti života. Društva koja osiguravaju pristup pravodobnim i relevantnim informacijama svim građanima uspješnija su u iskorjenjivanju siromaštva i nejednakosti, podupiru razvoj gospodarstva i poljoprivrede, omogućuju kvalitetnije obrazovanje te pozitivno utječu na ljudsko zdravlje, kulturu, istraživanja i inovacije.

Mreža Knjižnica grada Zagreba provodi niz aktivnosti kojima se uključuje i podupire ostvarivanje ciljeva Agende Ujedinjenih naroda za održivi razvoj 2030.,

1 Hrvatsko knjižničarsko društvo. Skupovi. [citirano:2019-11-08]. Dostupno na: http://hkdrustvo. $\mathrm{hr} / \mathrm{hr} /$ skupovi/skup/363/. 
u skladu s razvojem nacionalnog strateškog plana Republike Hrvatske koji je predstavljen na zasjedanju UN-a sredinom 2019. godine. Svaka knjižnica iz zagrebačke mreže svojim posebnostima pridonosi njihovu ostvarivanju, pa tako i Bibliobusna služba. I prema IFLA-inim Smjernicama za pokretne knjižnice, kao osnovna svrha svake službe pokretne knjižnice navodi se "promicati jednakopravnost u pružanju knjižničnih usluga povećanjem mogućnosti pristupa istima”. ${ }^{2}$

U sljedećim poglavljima napravljena je usporedba dijelova iz Smjernica za pokretne knjižnice s ciljevima Agende UN-a koje Bibliobusna služba Knjižnica grada Zagreba nastoji ispuniti svojim djelovanjem na prostoru Grada Zagreba i Zagrebačke županije. Riječ je o sljedećim ciljevima: Cilj 4-Kvalitetno obrazovanje, Cilj 10 - Smanjenje nejednakosti, Cilj 11 - Održivi gradovi i zajednice, Cilja 16-Mir i pravednost i Cilj 17 - Partnerstvo za održivi razvoj.

\section{Pokretne knjižnice i njihova obilježja}

Začetak pokretnih knjižnica u Hrvatskoj bilježi se 1911. godine kada su se na području Karlovačke županije knjige razvozile kočijom u drvenim sanducima. Sedamdesetih godina 20. stoljeća, u prigradskim naseljima hrvatskih gradova, raste broj obrazovanog stanovništva sa sve izraženijom kulturom čitanja te jača potreba za uspostavnom pokretnih knjižnica. Godine 1969. prvi namjenski uređen bibliobus počinje s radom u Rijeci, a 1976. godine započinje s radom i Bibliobusna služba Knjižnica grada Zagreba.

Usluge pokretne knjižnice važne su za djelatnost narodne knjižnice i trebamo ih promatrati kao njezin sastavni dio, a opći cilj pokretne knjižnice jest promicati jednakopravnost u pružanju knjižničnih usluga povećanjem mogućnosti pristupa istima. Pokretna knjižnica pruža najprilagodljiviju knjižničnu uslugu, nije ograničena na neko određeno mjesto stanovanja i sposobna je odgovoriti na potrebe promjenjivoga stanovništva. ${ }^{3}$ Budući da zbog naglog širenja grada nije bilo moguće istovremeno otvoriti dovoljan broj novih knjižnica, zaključeno je da se taj problem može ublažiti uvođenjem pokretne knjižnice. Prednost je pokretne knjižnice to što $\mathrm{s}$ istim fondom, osobljem i opremom može pružiti knjižničnu uslugu stanovništvu na međusobno udaljenim područjima, ali i senzibilizirati kritičnu masu čitatelja za korištenje buduće stacionirane knjižnice. ${ }^{4}$ Sukladno Standardima za pokretne knjižnice objavljenim u Narodnim novinama 1999. navodi se broj stajališta bibliobusa, vrijeme posjeta jednom stajalištu, broj sati rada s korisnicima tjedno i

\footnotetext{
2 Smjernice za pokretne knjižnice / prerađeno izdanje priredila radna skupina IFLA-ine Sekcije za narodne knjižnice na čelu s Ianom Stringerom. 1. hrvatsko izd. (prema 2. prerađenom izd. izvornika). Zagreb: Hrvatsko knjižničarsko društvo, 2011. Str. 11.

3 Isto, str. 11.

4 Knjižnica u pokretu: 40 godina zagrebačke bibliobusne službe. Zagreb: Knjižnice grada Zagreba, 2016. Str 5.
} 
zadržavanje na stajalištima koja se moraju razraditi vodeći računa o ekonomičnosti dnevne rute i tome da broj stajališta ovisi o vremenu (turnusu) posjeta istom stajalištu, kapacitetu bibliobusa te gustoći naseljenosti, odnosno veličini ustanove ili druge pravne osobe u koju bibliobus dolazi. Donju granicu opravdanosti čini 8, a gornju 20 stajališta u dvotjednom ciklusu. Udaljenost između dva stajališta, odnosno stacionirane knjižnice i bibliobusnog stajališta treba biti 1,5 do $2 \mathrm{~km}$, tj. najviše 20 minuta hoda. ${ }^{5}$

Usluge pokretne knjižnice važne su za djelatnost narodne knjižnice i trebamo ih promatrati kao njezin sastavni dio, a opći cilj pokretne knjižnice jest promicati jednakopravnost u pružanju knjižničnih usluga povećanjem mogućnosti pristupa istima.

\section{Bibliobusna služba Knjižnica grada Zagreba}

Bibliobusna služba Knjižnica grada Zagreba od 1976. godine djeluje na području Grada Zagreba i Zagrebačke županije. Osnovana je s ciljem širenja knjige i kulture čitanja u tzv. bijela područja, odnosno gradska i prigradska naselja u kojima nisu postojale stacionirane knjižnice. Svoj rad započela je nakon što je Matična i razvojna služba Knjižnica grada Zagreba planskim istraživanjem tijekom godina utvrdila veliku neujednačenost, a time i neravnopravan položaj stanovnika koji žive na periferiji i onih koji su bliže centru grada glede dostupnosti knjige. ${ }^{6}$ Bibliobus je pojavljivanjem na zagrebačkim ulicama izazivao oduševljenje, a broj stajališta bio je izuzetno velik jer su stajališta bila u područjima bez stacioniranih knjižnica. Prema podacima iz objedinjenog anketnog upitnika za pokretne knjižnice Republike Hrvatske Pokretne knjižnice RH stanje u 2018. godini ${ }^{7}$, kroz 42 godine djelovanja služba je od jednog vozila i 20 stajališta narasla na dva suvremeno opremljena vozila, od kojih je jedan bibliobus, a drugi bibliokamion, te 77 stajališta i 13 zaposlenika, osiguravajući svim građanima pristup građi i informacijama, razvijajući čitalačke navike, pismenost i književnu kulturu, pružajući mogućnosti za stalno samoobrazovanje, cjeloživotno učenje i zadovoljavanje potreba svih korisnika. Sukladno podacima iz Godišnjeg izvještaja Knjižnica grada Zagreba ${ }^{8}$, na dan 31. 12. 2018. fond Bibliobusne službe iznosi 66111 svezaka knjižnične građe.

\footnotetext{
5 Standardi za narodne knjižnice u Republici Hrvatskoj. Standardi za pokretne knjižnice. // Narodne novine 58, 1071(1999). [citirano:2019-11-08]. Dostupno na: https://narodne-novine. nn.hr/clanci/sluzbeni/1999_06_58_1071.html.

6 Usp. Pugelnik, Đ. Bibliobusna služba Knjižnica grada Zagreba. // Pokretne knjižnice u Hrvatskoj / uredile Ljiljana Vugrinec, Ljiljana Črnjar, Frida Bišćan. Zagreb: Hrvatsko knjižničarsko društvo; Karlovac: Gradska knjižnica Ivan Goran Kovačić, 2012. Str. 132.

7 Hrvatsko knjižničarsko društvo. Dokumenti i linkovi. [citirano:2019-11-08]. Dostupno na: https://www.hkdrustvo.hr/hr/strucna_tijela/37/publikacije/.

8 Knjižnice grada Zagreba. Godišnji izvještaji. [citirano: 2019-11-08]. Dostupno na: http://www. kgz.hr/hr/o-nama/godisnji-izvjestaji/43616.
} 
Fond je smješten u podrumske prostorije Knjižnice Voltino. U 2018. godini, s dva bibliobusna vozila i trinaest članova posade, obilazi 77 stajališta $^{9}$ i ima 4505 aktivnih članova. Uspoređujući broj aktivnog članstva u 2018. godini s ukupnim brojem aktivnog članstva u 2017., u 2018. godini bilježimo porast od 5,13\%. Na stajališta Bibliobusna služba dolazi svaka dva tjedna u isto vrijeme. Bibliobusna vozila različitih su kapaciteta, u većem je svakodnevno oko 7000, a u manjem 4000 svezaka knjižnične građe. Knjižnu građu moguće je posuditi na rok od 30 dana s mogućnošću produljenja, dok je audiovizualnu, elektroničku i prilagođenu građu moguće posuditi na 14 dana, također s mogućnošću produljenja.

Najvažnije dobne korisničke skupine čine djeca i mladi od najranije do tinejdžerske dobi te stariji - šezdeset pet plus. Te korisničke skupine važnije su primjerice od studenata ili radno aktivne skupine prvenstveno s obzirom na njihovu smanjenu mobilnost vezanu uz dob i zdravstveno stanje. Svaka od tih skupina ima različite potrebe i interese kojima posredno sudjeluju u kreiranju aktivnosti i nabavi građe. Dugi niz godina ostvaruje se izvrsna suradnja s ravnateljima škola i dječjih vrtića, nastavnicima, odgajateljima i školskim knjižničarima te ravnateljima i socijalnim radnicima u domovima za starije i nemoćne. Autorica M. Čudina-Obradović ističe kako se usluge pokretne knjižnice u školama i predškolskim skupinama smatraju "bitnom nadopunom obrazovnog postupka kroz opći model usluge pokretne knjižnice koji uključuje posjete školama, bilo kao dio uobičajene rute, bilo kroz pružanje specijaliziranih usluga. ${ }^{" 10}$

Bibliobusna služba sudjeluje i u vrijednom projektu Knjižnica grada Zagreba Knjigom do krova. ${ }^{11}$ Projekt je izvorno osmišljen kao pomoć sve značajnijoj populaciji beskućnika na području grada Zagreba.

Vrijednost Bibliobusne službe Knjižnica grada Zagreba leži upravo u činjenici da jača humanu komponentu knjižnične djelatnosti. Djelatnici su spremni u svakom trenutku izići u susret željama i potrebama svojih članova. Bibliobusna služba, stavljanjem posebnog naglaska na ljudski aspekt komunikacije s korisnicima, znatno doprinosi razvoju suvremene knjižnične djelatnosti na području Grada Zagreba i Zagrebačke županije.

\subsection{Poslanje Bibliobusne službe Knjižnice grada Zagreba}

Bibliobusna služba, u sklopu mreže Knjižnica grada Zagreba, danas ima posebno važnu ulogu. U vrijeme kada otuđenje i usamljenost uzimaju sve više maha u društvu, bibliobus sa svojom posadom, usredotočenom na želje i potrebe kori-

\footnotetext{
9 Bibliobusna služba. Raspored stajališta. // Knjižnice grada Zagreba. [citirano: 2019-09-10]. Dostupno na: http://www.kgz.hr/hr/knjiznice/bibliobusna-sluzba/raspored-i-stajalista/247.

10 Čudina-Obradović, M. Igrom do čitanja. Zagreb: Školska knjiga, 1995. Str. 14.

11 Knjižnice grada Zagreba. Knjigom do krova. [citirano: 2019-06-10]. Dostupno na: https:// beskucnik.kgz.hr/projekt/.
} 
snika, posebno onih željnih razgovora i razmjene informacija, predstavlja svojevrsni bastion humanosti i razumijevanja te intelektualnog općenja na relaciji knjižničar-korisnik. Posebice treba istaknuti djecu i mlade od najranije pa do tinejdžerske dobi koji, korak po korak, koriste prve slikovnice, lektirnu građu, knjige za odmor i zabavu te stručnu literaturu, a žive u područjima prilično udaljenima od prve stacionirane knjižnice. Prema Pravilima Knjižnica grada Zagreba ${ }^{12}$ Bibliobusna služba omogućuje i besplatan upis djece do 15 godina s prebivalištem u gradu Zagrebu i gradu Zaprešiću. Promicanjem Projekta 65 plus, namijenjena društvenoj integraciji osoba treće životne dobi i njihovu aktivnom uključivanju u kulturna i društvena zbivanja, Bibliobusna služba vodi brigu i o korisnicima treće životne dobi. Intenzivirana je i nabava audiovizualne i elektroničke građe koja obuhvaća i prilagođenu građu u DAISY-book-formatu, namijenjenu slijepim i slabovidnim osobama.

Organizacijom raznih aktivnosti, putujućim izložbama, promicanjem važnosti medijske pismenosti, suradnjom s kulturnim, odgojno-obrazovnim i znanstvenim institucijama te brojnim korisnicima, dokazuje svoju važnost u društvu i nezamjenjivu ulogu u lokalnoj zajednici.

Od 2017. godine Bibliobusna služba uključila se u promicanje projekata, aktivnosti i manifestacija kao što su Mjesec hrvatske knjige, Projekt 65 plus, Kampanja Čitaj mi!, Noć muzeja, Noć knjige, Dani medijske pismenosti, a po prvi put i organizirajući vlastite programe.

U lipnju svake godine radi se evaluacija, a potom priprema i reorganizacija bibliobusnih stajališta koja se počinju obilaziti početkom sljedeće školske godine. Sukladno evaluaciji stajališta u lipnju, otvaraju se nova te zatvara dio postojećih stajališta za koja je utvrđeno da više nisu potrebna u Gradu Zagrebu i Zagrebačkoj županiji. Reorganizacija se radi s ciljem promicanja jednakopravnosti u pružanju knjižničnih usluga i povećavanjem mogućnosti pristupa istima. Važno je istaknuti otvaranje bibliobusnog stajališta u gradu Sveta Nedjelja, jedinom gradu u Zagrebačkoj županiji koji nema stacioniranu knjižnicu, u travnju 2018. godine.

\section{Ispunjavanje ciljeva Agende UN-a: primjeri dobre prakse}

Bibliobusna služba uključena je u niz aktivnosti u svrhu ostvarivanja zadanih ciljeva Agende UN-a za održivi razvoj. Za sada svojim radom nastoji doprinijeti sljedećim ciljevima: Cilju 4. - Kvalitetno obrazovanje, Cilju 10. - Smanjenje nejednakosti, Cilju 11. - Održivi gradovi i lokalne zajednice, Cilju 16. - Mir i pravednost, Cilju 17. - Partnerstvo za ciljeve.

12 Knjižnice grada Zagreba. Pravila Knjižnica grada Zagreba. [citirano: 2019-11-08]. Dostupno na: http://www.kgz.hr/hr/informacije/upisi-i-posudba-196/pravila-knjiznica-gradazagreba-40217/40217. 


\subsection{Cilj 4. - Kvalitetno obrazovanje.}

Mjesec hrvatske knjige manifestacija je koja promiče knjigu i čitanje kao društvenu vrijednost na nacionalnoj razini. Od 1995. godine, a pod pokroviteljstvom Ministarstva kulture, organiziraju je i realiziraju Knjižnice grada Zagreba. Riječima autorice Čudine-Obradović kako je u suvremenom svijetu čitanje vještina koja je nužna za opstanak, ali i da ta vještina nije posljedica biološkoga, nego kulturnog razvoja čovjeka ${ }^{13}$, Bibliobusna je služba bila potaknuta aktivno se, organizacijom događanja, uključiti u Mjesec hrvatske knjige 2017.

Prvo takvo događanje u 2017. održano je pod nazivom Deveta umjetnost pod visokom Fibrom. Gost je bio Marko Šunjić, vlasnik izdavačke kuće Fibra, a razgovaralo se o razvoju stripa u Hrvatskoj i svijetu i utjecaju stripa na razvoj čitateljskih navika. Susret s Markom Šunjićem održan je 16. listopada 2017. u bibliokamionu na parkiralištu ispred Muzeja Mimara u Zagrebu. Događanje je bilo namijenjeno mladoj i odrasloj populaciji, a prisustvovalo mu je dvadeset pet posjetitelja.

Vođena Smjernicama za knjižnične usluge za djecu IFLA-e $i$ Konvencijom o pravima djeteta Ujedinjenih naroda koja naglašava pravo svakog djeteta da u potpunosti razvije svoje potencijale, pravo na slobodan i besplatan pristup informacijama, građi i programima pod jednakim uvjetom za sve i bez obzira na dob ${ }^{14}$ te Ciljem 4 Agende UN-a, u ožujku 2018. Bibliobusna služba priključuje se prvoj nacionalnoj kampanji za promicanje čitanja naglas djeci od rođenja Čitaj mi!!15. Knjižničnim fondom, aktivnostima i promicanjem sadržaja važnih za odgoj čitatelja od malih nogu, potiču se roditelji i drugi odrasli da s čitanjem naglas djetetu započnu već od njegova rođenja kako bi čitanje postalo dijelom svakodnevnog ugodnog druženja roditelja i djece te kako bi se stvorila posebna emocionalna veza između djeteta i odrasle osobe koja mu čita. Djeca u bibliobusu stvaraju svoja prva prijateljstva, a roditelji pronalaze nova. Stvara se navika dolaska u bibliobus, odnosno navika čitanja. Mnoga djeca dugo će pamtiti slikovnice koje su posuđivala u bibliobusu, one će ih i u kasnijoj dobi podsjećati na to da su bibliobus i čitanje bili sastavni dio njihova života odmalena. Zadržat će ljubav prema čitanju, a naviku čitanja tako će prenijeti i na svoju djecu. Time se važnost postojanja i djelovanja Bibliobusa prenosi s generacije na generaciju, a pokretna knjižnica živi i djeluje kao bitan segment svakodnevnog života.

Jedna od ključnih vještina 21. stoljeća jest medijska pismenost. Potrebna je jednako i djeci i odraslima kako bi medije znali koristiti za svoje i opće dobro. Radi mogućnosti što boljeg upoznavanja javnosti s osnovama medijske pismenosti, Agencija za elektroničke medije i Ured UNICEF-a za Hrvatsku, pod pokroviteljstvom Ministarstva kulture i Ministarstva znanosti i obrazovanja, u suradnji s

13 Čudina-Obradović, M. Nav. dj., str. 15.

14 Smjernice za knjižnične usluge za djecu. Zagreb: Hrvatsko knjižničarsko društvo, 2004. Str. 5.

15 Čitaj mi!. Kampanja. [citirano 2018-11-01]. Dostupno na: http://www.citajmi.info/kampanja/. 
brojnim partnerima i medijskim kućama u travnju 2018. pokrenuli su Dane medijske pismenosti koji su svoj nastavak imali i u travnju 2019. ${ }^{16}$ U Danima medijske pismenosti Bibliobusna služba predstavila je korisnicima na redovnim stajalištima u Gradu Zagrebu i Zagrebačkoj županiji slikovnicu Slikovnica o medijima - medijska pismenost za najmlađe. Ta publikacija dio je edukacijskog paketa za predškolce, koji su Agencija za elektroničke medije i UNICEF u suradnji s domaćim stručnjacima pripremili za Dane medijske pismenosti. Namijenjena je djeci, roditeljima, skrbnicima i odgajateljima, a svrha joj je kroz igru i istraživanje dati djeci priliku za razumijevanje medija. ${ }^{17}$

Praćenje potreba suvremenih korisnika potaknulo nas je na to da se uključimo u projekte Instituta za razvoj i inovativnost mladih (IRIM - Croatian Makers), a s ciljem predstavljanja novih tehnologija djeci koja žive u rubnim naseljima i pohađaju područne škole. To su projekti STEM-revolucija se nastavlja: Knjižnice i Digitalni građanin kojima se potiče korištenje digitalnih tehnologija u knjižnicama kako bi se upravo knjižnice razvile u napredne centre za stjecanje digitalnih vještina. Donacijom IRIM-a i Rotary-kluba Zagreb Centar u 2018. godini Bibliobusna služba proširila je svoju audiovizualnu i elektroničku zbirku BBC-micro:bitovima ${ }^{18}$ namijenjenim učenju osnova programiranja. U 2019. godini ista zbirka donacijom IRIM-a dopunjena je setom BOSON-elemenata koji u kombinaciji s BBC-micro:bitovima omogućava različite mogućnosti pri programiranju. Projektom posudbe micro:bitova nastavlja se dugogodišnja praksa promicanja novih tehnologija i dopiranja do one djece koja nemaju pristup istima, ali i do odraslih korisnika kako bi i oni usvojili potrebna znanja i vještine potrebne u 21. stoljeću. Dvadeset micro:bitova predviđeno je za posudbu korisnicima, uz prethodni dogovor s informatorima, na rok od četrnaest dana. Institut za razvoj i inovativnost mladih pozvao je sve osnovne škole, udruge, knjižnice i druge ustanove koje sudjeluju u IRIM-ovim projektima na konferenciju Croatian Makers koja je održana u svibnju 2018. u Tehnološkom parku Zagreb, u 12. paviljonu Zagrebačkog Velesajma, a na kojoj je s micro:bitovima i materijalima o posudbi istih sudjelovala i Bibliobusna služba Knjižnica grada Zagreba ispred Komisije za pokretne knjižnice Hrvatskog knjižničarskog društva. Konferencija je bila otvorenog tipa te su joj se mogli pridružiti svi oni koje zanima edukacijska tehnologija IRIM-a kako bi ujedno upoznali praktične primjere i projekte u kojima je tehnologija korištena. Zahvaljujući posudbi micro:bitova u Bibliobusu, neke su škole pokrenule samostalne radionice, dok je Bibliobusna služba redovite uvodne radionice pro-

\footnotetext{
16 Dani medijske pismenosti. // Medijska pismenost.hr. [citirano: 2019-11-08]. Dostupno na: https://www.medijskapismenost.hr/dani-medijske-pismenosti/.

17 Prva hrvatska slikovnica o medijskoj pismenosti za najmlađe. // Medijska pismenost. hr. [citirano: 2019-11-08]. Dostupno na: https://www.medijskapismenost.hr/prva-hrvatskaslikovnica-o-medijskoj-pismenosti-za-najmlade/.

18 BBC micro:bit: edukacijski materijali. // Izradi![citirano:2019-11-08]. Dostupno na: http:// izradi.croatianmakers.hr/bbc-microbit-uvodna-stranica/.
} 
gramiranja s micro:bitovima održavala u OŠ Voltino. Po primitku donacije seta dodataka BOSON od IRIM-a u travnju 2019., napredovale su i radionice programiranja s micro:bitovima jer su se sada u njima koristili i novi donirani elementi. U razdoblju od 9. studenog 2018. do 9. lipnja 2019. provedeno je 11 radionica na kojima je sudjelovalo 250 učenika nižih razreda OŠ Voltino.

Od 31. svibnja do 1. lipnja 2018. u Pečuhu, Mađarska, održan je II. međunarodni susret bibliobusa. Naglasak skupa bio je na ulozi pokretne knjižnice kao veze sa svijetom u smislu osiguravanja dostupnosti knjižnične građe za čitanje i učenje, ali i omogućavanja pristupa internetu i novim tehnologijama općenito te različitim drugim uslugama koje su s tim tehnologijama povezane.

Susretu su prisustvovali predstavnici knjižnica i bibliobusnih službi iz sedam europskih zemalja - Mađarske, Hrvatske, Srbije, Slovenije, Njemačke, Nizozemske i Rumunjske. Teme konferencije bile su aktivnosti i obrazovno-kulturni programi knjižnica i bibliobusa usmjereni obrazovnom, kulturnom i tehnološkom osnaživanju stanovnika ruralnih područja, osobito djece i mladih koji imaju manje mogućnosti sudjelovanja u takvim aktivnostima zato što žive u malim naseljima, udaljenima od većih središta. Bibliobusna služba Knjižnica grada Zagreba predstavila se izlaganjem na posteru pod naslovom Mobile Library Service of Zagreb City Libraries - Examples of Good Practice: Can't make it to one of our branches? Don't worry, we'll come to you.

\subsection{Cilj 10. - Smanjenje nejednakosti.}

Prema Smjernicama za pokretne knjižnice, najnoviji je trend da specijalno vozilo ima osobna računala s pristupom internetu, skener i fotokopirni uređaj, DVDove i CD-ove, mogućnost prijenosa podataka te slušaonicu. ${ }^{19}$

Od 2017. godine fond Bibliobusne službe bogatiji je za zbirku audiovizualne i elektroničke građe. U AV- i e-zbirci uz animirane, dokumentarne i igrane filmove na DVD-u te micro:bitove nalazi se i prilagođena građa u DAISY-book-formatu namijenjena prvenstveno slijepim i slabovidnim osobama.

U travnju 2018. voditeljica Bibliobusne službe sudjelovala je na seminaru i radionici za knjižničare o integracijskim teorijama i praksama, održanu u sklopu istoimenog projekta Migranti u knjižnici / Migrate to library koji je za glavne ciljeve imao razmjenu dobre prakse i stjecanje kompetencija koje će koristiti knjižničarima kako bi na neformalan način korisnicima pojasnili pojmove poput inkluzije migranata te ih informirali o načinima suzbijanja segregacije i diskriminacije._Koordinator projekta Migranti u knjižnici / Migrate to library bila je Narodna knjižnica Općine Zory iz Poljske, a uz Gradsku knjižnicu Ivan Vidali iz

19 Smjernice za pokretne knjižnice. Nav. dj., str. 14. 
Korčule partneri su i Narodna knjižnica u Arucasu iz Španjolske i Narodna knjižnica u Vilniusu iz Litve.

\subsection{Cilj 11. - Održivi gradovi i lokalne zajednice.}

Smjernice za pokretne knjižnice navode da postoje posebne službe za pružanje knjižničnih usluga ljudima koji su više ili manje vezani uza svoje domove, za osobe starije životne dobi ili osobe s invaliditetom. U zemljama s prosječno starim stanovništvom sve je veći naglasak na zadovoljavanju potreba manje pokretnih članova zajednice ${ }^{20}$ te mnoge pokretne knjižnice posjećuju umirovljenička naselja i domove, što može uključivati uslugu za hospicije te domove za starije i nemoćne osobe. ${ }^{21}$ Knjižnice grada Zagreba provode ciljane programe namijenjene društvenoj integraciji osoba treće životne dobi i njihovu aktivnom uključivanju u kulturna i društvena zbivanja, pri čemu se posebna pozornost pridaje osnaživanju u području zaštite njihovih ljudskih, materijalnih, zdravstvenih i socijalnih prava. ${ }^{22}$

Od listopada 2017. godine Bibliobusna služba Knjižnica grada Zagreba promiče Projekt 65 plus kroz jedan od programa projekta - Knjigom do vrata. Ostvarena je suradnja s dva doma za starije i nemoćne osobe, gdje su osnovana i nova bibliobusna stajališta, a to su Zlatno doba - dom za starije i nemoćne osobe u Pušći i Dom za starije i nemoćne osobe Sanatorij Ćorluka u Zagrebu. U sklopu programa Knjigom do vrata, a prilikom obilaska postojećih stajališta, Bibliobusna služba također odlazi i u individualne posjete. U 2018. godini Bibliobusna služba posjetila je oba doma ukupno četrdeset četiri puta, a u obje induvidualne posjete otišla je ukupno dvadeset četiri puta.

\subsection{Cilj 16. - Mir i pravednost.}

U Noći knjige 2018. godine, u suradnji s pitomcima policijske akademije u Zagrebu kao budućim službenim osobama koje se bave održavanjem mira i sigurnosti svih građana Republike Hrvatske, Bibliobusna služba na parkiralištu ispred Policijske akademije predstavila je način rada pokretne knjižnice te pokazala njezin značaj u društvu i lokalnoj zajednici, pri čemu je omogućeno razgledavanje biliobusa. Tom prilikom zabilježeno je 220 posjeta pitomaca. Program je realizirala Policijska škola "Josip Jović", Odjel za nakladničku djelatnost i Muzej policije MUP-a u suradnji s Visokom policijskom školom i Bibliobusnom službom Knjižnica grada Zagreba.

\footnotetext{
20 Isto, str. 14.

21 Isto, str. 15.

22 Knjižnice grada Zagreba. 65 plus. [citirano: 2019-11-11]. Dostupno na: http://www.kgz.hr/ hr/65-plus-1296/1296.
} 


\subsection{Cilj 17. - Partnerstvo za održivi razvoj.}

Prema Standardima za pokretne knjižnice, bibliobusna služba treba stalno surađivati s jedinicama lokalne samouprave, odgojno-obrazovnim ustanovama i drugim pravnim osobama na području svoga djelovanja, s ciljem pridobivanja novih članova i kulturne animacije. ${ }^{23}$ U Mjesecu hrvatske knjige 2017. postavljena je prva putujuća izložba u bibliobusu naziva Lutke skitalice svestrane umjetnice Margarete Peršić iz Zagreba. U suradnji s Margaretom Peršić Bibliobusna služba sudjelovala je u promicanju lutkarstva kao posebne grane kazališne umjetnosti. U Mjesecu hrvatske knjige 2018. u suradnji sa Zagrebačkim kazalištem lutaka postavljena je druga putujuća izložba u bibliobusu pod nazivom Lutke na kotačima tijekom koje su izložene lutke iz nekih poznatih dječjih lutkarskih predstava kreatorice Vesne Balabanić. Obje izložbe izazvale su oduševljenje i mlađih i starijih posjetitelja na bibliobusnim stajalištima u Gradu Zagrebu i Zagrebačkoj županiji.

Bibliobusna služba po prvi je put u siječnju 2018. godine sudjelovala u Noći muzeja. Manifestacija se održala pod olimpijskim geslom Važno je sudjelovati i naslovom Muzeji i sport - brže, više, jače / citius, altius, fortius. Tom prigodom posjetitelji Muzeja Mimara mogli su razgledati i unutrašnjost knjižnice na kotačima, doznati o specifičnostima njezina rada te razgledati tematsku zbirku naslova knjiga o sportu. U bibliobusu su tada zabilježena 202 posjetitelja. Time je Bibliobusna služba u svrhu promicanja knjige i čitanja ostvarila odlično partnerstvo s Muzejom Mimara. Suradnja s Muzejom Mimara nastavila se u 2019. kada je Bibliobusna služba sudjelovala u Noći muzeja pod nazivom Muzeji - Inovacije $i$ digitalna budućnost. Tom prigodom posjetitelji Bibliobusa mogli su razgledati posebnu zbirku naslova knjiga pod nazivom Od Gutenberga do Zuckerberga, natjecati se u kvizu Bibliobus u Noći muzeja te sudjelovati na pokaznoj radionici programiranja s BBC-micro:bitovima. U bibliobusu je tada zabilježeno 300 posjetitelja.

U suradnji s Gradskom knjižnicom Krapina i Srednjom školom Krapina u ožujku 2018. Bibliobusna služba predstavila je način rada pokretne knjižnice na Danu bajki i priča pod naslovom Baj(kaj)mo i pri(ča)jmo s ma(što)m te ostvarila partnerstvo s Gradskom knjižnicom Krapina.

\section{Zaključak}

Bibliobusna služba svojim dosadašnjim aktivnostima doprinosi ostvarenju tek nekoliko od sedamnaest ciljeva Agende UN-a. Kako bi se brojnost ciljeva i mogućnosti njihove brže i uspješnije realizacije ostvarili, potrebno je realizirati i neke preduvjete: obnoviti vozni park Bibliobusne službe, a sukladno potrebama korisnika, nužno ga je opremiti suvremenom tehnologijom. Suvremena tehnolo-

23 Standardi. Nav. dj. 
gija podrazumijeva sljedeće: pristup za osobe s invaliditetom, računalo za slijepe i slabovidne osobe, računalnu multi-touch-opremu za korisnike, pristup internetu, wifi, nabavu softvera koji se može koristiti u različitim područjima osnovnoškolskog obrazovanja, skener i printer za korisnike, zaslon s mogućnošću prikazivanja edukativnih filmova i prezentacija te zaslon koji bi prikazivao informacije o Bibliobusnoj službi. Osim toga, nužno je da Bibliobusna služba i dalje nastavi istraživanja o potrebama korisnika i da s tim u vezi radi izmjene i dopune, kao i prilagodbe u nabavi knjižnične građe. Tako korisnici postaju značajni sudionici u kreiranju i realizaciji nabave građe. Pritom je vrlo važna suradnja i sa svim institucijama na terenu. U suradnji s predškolskim i osnovnoškolskim ustanovama potrebno je istraživanje usmjeriti i na učenje stranih jezika, pa tako nabavu knjižne građe obogatiti nabavom slikovnica i knjiga za djecu na stranim jezicima. Također, istraživanja na terenu treba proširiti na gluhe i nagluhe osobe te nabavom i za njih osigurati odgovarajuću knjižničnu građu. Bibliobusna služba treba i dalje istraživati, širiti, mijenjati mrežu stajališta i prilagođavati se potrebama korisnika koji su udaljeni od stacioniranih knjižnica u Gradu Zagrebu i Zagrebačkoj županiji, treba očuvati opstojnost trenutne mreže bibliobusnih stajališta, ali i težiti otvaranju novih. Realizacija ciljeva Agende UN-a i promicanje jednakopravnosti u pružanju najprilagodljivije knjižnične usluge povećavanjem mogućnosti pristupa istima prema potrebama promjenjivog stanovništva bez obzira na mjesto stanovanja ideja je vodilja Bibliobusne službe Knjižnica grada Zagreba.

Pružanjem bibliobusne usluge knjižničari nastoje smanjiti posljedice društvene isključenosti te podići kvalitetu i standard života u zajednici svih građana te tako pridonose ostvarivanju prava svakog pojedinca na pristup informacijama, znanju i kulturi.

\section{LITERATURA}

BBC micro:bit: edukacijski materijali. // Izradi! [citirano:2019-11-08]. Dostupno na: http://izradi.croatianmakers.hr/bbc-microbit-uvodna-stranica/.

Bibliobusna služba. Raspored stajališta. // Knjižnice grada Zagreba. [citirano: 201909-10]. Dostupno na: http://www.kgz.hr/hr/knjiznice/bibliobusna-sluzba/raspored-i-stajalista/247.

Čitaj mi!. Kampanja. [citirano: 2018-11-01]. Dostupno na: http://www.citajmi.info/ kampanja/.

Čudina - Obradović, M. Igrom do čitanja. Zagreb: Školska knjiga, 1995.

Hrvatsko knjižničarsko društvo. Skupovi. [citirano:2019-11-08]. Dostupno na: http:// hkdrustvo.hr/hr/skupovi/skup/363/. 
Hrvatsko knjižničarsko društvo. Dokumenti i linkovi. [citirano:2019-11-08]. Dostupno na: https://www.hkdrustvo.hr/hr/strucna_tijela/37/publikacije/.

Knjižnice grada Zagreba. Knjigom do krova. [citirano: 2019-06-10]. Dostupno na: https://beskucnik.kgz.hr/projekt/.

Knjižnice grada Zagreba. Godišnji izvještaji. [citirano: 2019-11-08]. Dostupno na: http://www.kgz.hr/hr/o-nama/godisnji-izvjestaji/43616.

Knjižnice grada Zagreba. 65 plus. [citirano: 2019-11-11]. Dostupno na: http://www.kgz. $\mathrm{hr} / \mathrm{hr} / 65$-plus-1296/1296.

Knjižnice grada Zagreba. Pravila Knjižnica grada Zagreba. [citirano: 2019-11-08]. Dostupno na: http:/www.kgz.hr/hr/informacije/upisi-i-posudba-196/pravila-knjiznica-grada-zagreba-40217/40217.

Dani medijske pismenosti. // Medijska pismenost.hr. [citirano: 2019-11-08]. Dostupno na: https://www.medijskapismenost.hr/dani-medijske-pismenosti/.

Standardi za narodne knjižnice u Republici Hrvatskoj. Standardi za pokretne knjižnice. // Narodne novine 58, 1071(1999). [citirano:2019-11-08]. Dostupno na: https://narodne-novine.nn.hr/clanci/sluzbeni/1999_06_58_1071.html.

Knjižnica u pokretu: 40 godina zagrebačke bibliobusne službe. Zagreb: Knjižnice grada Zagreba, 2016.

Pugelnik, Đ. Bibliobusna služba Knjižnica grada Zagreba. // Pokretne knjižnice u Hrvatskoj / uredile Ljiljana Vugrinec, Ljiljana Črnjar, Frida Bišćan. Zagreb: Hrvatsko knjižničarsko društvo ; Karlovac : Gradska knjižnica Ivan Goran Kovačić, 2012. Str. 129-137.

Smjernice za knjižnične usluge za djecu. Zagreb: Hrvatsko knjižničarsko društvo, 2004.

Smjernice za pokretne knjižnice. Zagreb: Hrvatsko knjižničarsko društvo, 2011. 